\title{
Santripreneur Penghasil Kerajinan dari Limbah Plastik di Kawasan Pondok Pesantren KH. Murodi Mranggen Demak
}

\author{
Muhdi, Sunan Baedowi, Mahmud Yunus, Achmad Buchori \\ Universitas PGRI Semarang, Semarang, Indonesia \\ muhdi@upgris.ac.id
}

Received: $5^{\text {th }}$ August 2020 | Accepted: $18^{\text {th }}$ July $2021 \mid$ Published: $27^{\text {th }}$ July 2021

\section{Key word:}

Santripreneur; plastic waste; variety of crafts

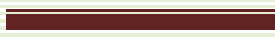

\section{Kata Kunci}

Santripreneur; Sampah plastik; variasi kerajinan tangan

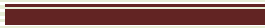

\section{Abstract}

The amount of plastic waste around the Mranggen Market and Pondok Pesantren K.H. Murodi Mranggen Demak is a cause for concern. Good waste management so that plastic waste has use value and is beneficial for the environment around Islamic boarding schools is the goal in this service. The methods used are: problem mapping, design, manufacture, operation test, operation assistance and marketing training for production products. The strategy used to make plastic waste valuable is by conducting training in making variations of plastic waste product crafts with Eco-Bricks made into chairs, flower vases, bags, wallets, prayer mats and others. In addition, it is to strengthen good waste management among students. The results of this santripreneur activity are 1) Santri feel excited to understand and do entrepreneurship/studentpreneurs from an early age; 2) students understand the importance of processing waste and the importance of providing added value to products made from plastic waste, 3) 80 percent of students are able to make variations of crafts from plastic waste and 20 percent still need further assistance, 4) marketing is carried out in collaboration with MSMEs in Indonesia. Semarang and Demak so that it can make passive income for students.

\section{Abstrak}

Banyaknya sampah plastik di sekitar Pasar Mranggen dan Pondok Pesantren K.H. Murodi Mranggen Demak menjadi keprihatinan tersendiri. Pengelolaan sampah yang baik agar sampah plastik memiliki nilai guna dan bermanfaat bagi lingkungan di sekitar Pondok Pesantren menjadi tujuan dalam pengabdian ini. Metode yang digunakan adalah: pemetaan masalah, perancangan, pembuatan, uji operasi, pendampingan operasi dan pelatihan pemasaran hasil produksi. Strategi yang digunakan agar sampah plastik bernilai guna yaitu dengan melakukan pelatihan pembuatan variasi kerajinan produk sampah plastik dengan Eco-Bricks dibuat menjadi kursi, vas bunga, tas, dompet, sajadah dan lainnya. Selain itu dengan memantapkan pengelolaan sampah yang baik di kalangan santri. Hasil kegiatan ini adalah 1) Santri merasa bersemangat untuk memahami dan melakukan wirausaha/santripreneur sejak dini; 2) santri memahami petingnya melakukan pengolahan sampah dan pentingnya memberikan tambahan nilai pada produk berbahan baku sampah plastic, 3) 80 persen para santri mampu membuat variasi kerajinan dari sampah plastik dan 20 persen masih perlu pendampingan lebih lanjut, 4)pemasaran dilakukan kerjasama dengan UMKM di Semarang dan Demak sehingga dapat menjadikan pasif income bagi para santri. 


\section{PENDAHULUAN}

Pondok Pesantren KH. Murodi merupakan salah satu Pondok Pesantren yang berlokasi di Jalan Suburan Barat RT 03/02, Kelurahan Mranggen Kecamatan Mranggen Kabupaten Demak Jawa Tengah. Pondok Pesantren KH. Murodi didirikan pada tahun 1952 oleh AlMaghfurlah Syekh KH. Murodi Bin Syekh KH. Abdurrahman. Saat ini, pengelolaan Pondok Pesantren dilanjutkan oleh putraputra beliau yaitu, KH. Agus Maghfur Murod dan KH. Abdul Choliq Murod, Lc. Pondok Pesantren KH. Murodi merupakan afiliasi dari Pondok Futuhiyyah dalam arti santrinya menuntut ilmu pada pagi hari di sekolah/madrasah Futuhiyyah seperti SMP, MTs, MA, SMK, dan SMA, sementara pada sore dan malam hari belajar di Pondok Futuhiyyah.

Visi dari Pondok Pesantren KH. Murodi yaitu "Terbentuknya Insan Kamil yang menguasai Ilmu Agama dan Ilmu Umum secara berimbang dengan dilandasi “Akhlak Al-Karimah”. Sedangkan Misi dari Pondok Pesantren KH. Murodi adalah (1) Membentuk Insan Kamil yang berkepribadian luhur dan bertanggung jawab dalam menjalankan syariat Islam dan akhlak al-karimah. (2) Mencetak Insan Kamil yang berpengetahuan luas dan mempunyai kompetensi yang tinggi dalam bidang agama dan umum. (3) Menciptakan dan mempelopori terbentuknya

"lingkungan masyarakat berbudaya Islam" atau biasa dikenal dengan Limabudi.

Kegiatan ekstrakurikuler di Pondok Pesantren KH. Murodi antara lain Pembinaan Tahfidz dan Tanfidz AlQur'an, marawis atau hadrah, Kajian kitab kuning, pidato, pramuka, komputer, bahasa asing, kaligrafi, silat, basket, voli, sepakbola, marching band, pengembangan jurnalistik dan publisistik, pengembangan Exacta (Lab Skill), Ketrampilan hidup/usaha. Kegiatan ketrampilan hidup/usaha dibutuhkan santri untuk bekal kehidupan setelah santri lulus dari Pondok Pesantren KH. Murodi, diharapkan selain bekal agama santri juga mendapatkan bekal ketrampilan dibidang usaha.

Hasil observasi yang dilakukan oleh Tim Pengabdi di lokasi mitra Pondok Pesantren KH. Murodi, tim pengabdi menemukan tumpukan sampah plastik dalam jumlah banyak di belakang Pasar Mranggen yang tidak diberdayakan dan di area pondok pesantren KH. Murodi. Berdasarkan hasil wawancara yang dilakukan dengan Pengurus Pondok Pesantren KH. Murodi, didapatkan informasi bahwa jumlah sampah plastik dibelakang area Pondok Pesantren menjadi permasalahan yang menganggu bagi Pondok Pesantren terutama dari sisi kebersihan 


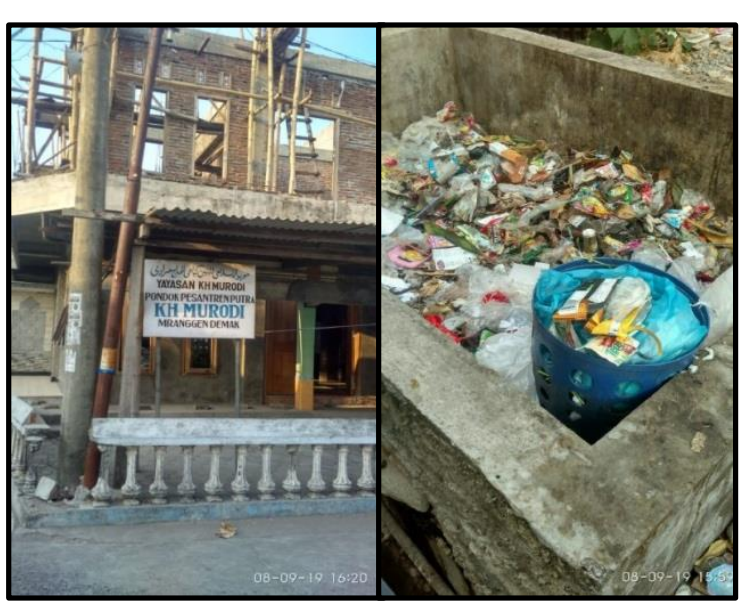

Gambar 1. Sampah plastik di area pasar Mranggen dan area pondok

Berdasarkan diskusi antara Tim Pengabdi dengan Pengurus Pondok Pesantren KH. Murodi maka diperlukan upaya penyelesaian permasalahan plastik sampah.

Penelitian yang dilakukan oleh Alrashid, \& Kahdar menunjukkan bahwa dengan pemberian edukasi mengenai eksplorasi sampah plastik menggunakan metode fabrikasi untuk produk fashion menjadikan para perempuan memiliki ketrampilan lebih dalam mengemas produk fashion (Alrashid \& Kahdar, 2014). Selain itu, penelitian mengenai pemanfaatan sampah plastik menjadi produk kerajinan tangan bernilai ekonomis bagi remaja putus sekolah menunjukkan bahwa anak remaja putus sekolah sangat senang diberik ketrampilan dalam membuat produk dari sampah plastik (Diana dkk., 2017). Mengenai pemasaran hasil produk olahan sampah sempat diteliti oleh Mahmud Yunus yang menunjukkan pengaruh gojek sebagai simbol perubahan sosial dan ekonomi di Jawa Tengah bahwa dengan GoJek, berbagai produk bisa mudah terdistribusikan ke masyarakat (Yunus, 2017).

Pengabdian yang telah dilakukan di Pondok Pesantren KH Murodi menunjukkan antusiasme santri atas ilmu dan pengalaman baru, utamanya untuk penerapan IT (Widianto dkk., 2017). Berkaitan dengan softskill bagi para santri, Muhdi telah melakukan penelitian tentang Pendidikan Kecakapan Hidup (Life Skills) Melalui Child Friendly Teaching Model (CFTM) Sebagai Dasar Membangun Karakter Siswa, dengan kecakapan hidup menjadikan para santri nantinya mampu mengarungi kehidupan yang keras dan membutuhkan skill yang baik (Muhdi dkk., 2012).

Berdasarkan kondisi awal dan beberapa penelitian atau pengabdian terkait santri dan sampah, tim pengabdi menawarkan solusi untuk menyelesaikan permasalahan mitra sekaligus untuk menciptakan santripreneur dikalangan santri yang diselaraskan dengan kegiatan Koperasi Pondok Pesantren KH. Murodi, yaitu dengan pelaksanaan program PKM Santripreneur Penghasil Kerajinan dari Limbah Plastik. 


\section{METODE}

Program pengabdian kepada masyarakat di Desa Mranggen Kecamatan Mranggen Kabupaten Demak melibatkan LPPM UPGRIS sebagai lembaga LITBANG memilih Pondok Pesantren KH Murodi sebagai mitra. Pemilihan pesantren tersebut didasarkan pada permasalahan mitra yang membutuhkan pendampingan dalam pengolahan sampah plastik

Metode serta tahap-tahap Penerapan teknologi kepada masyarakat mellaui beberapa metode dan tahap, meliputi :

a. Identifikasi Kebutuhan santri, dilakukan dengan observasi dan wawancara langsung dengan kelompok santri, meliputi produksi kerajinan sampah plastik, pemasaran produk dari sampah plastik, maupun upaya alternatif mengolah sampah plastik.

b. Perancangan, yaitu mendiskusikan rancangan program untuk mengolah sampah plastik dan alternatif variasi produk yang dapat dikomersialisasikan

c. Pembuatan, Tim pengabdian bersama dengan anggota kelompok santri membuat variasi kerajinan sampah plastik. Keterlibatan anggota santri untuk memberikan masukan terhadap pembuatan kerajinan sampah plastik.

d. Uji operasi dan pendampingan operasional. Uji operasi dan pendampingan operasional dilaksanakan dalam rangka menguji kesesuaian produk variasi kerajian limbah plastik dengan kebutuhan masyarakat

e. Melatih manajemen pemasaran maupun finansial agar para santri mampu menghasilkan pasif income tanpa merepotkan orangtua mereka masing-masing.

\section{HASIL}

Hasil identifikasi kebutuhan mitra yaitu santri ponpes $\mathrm{KH}$ Murodi menunjukkan bahwa pondok pesantren $\mathrm{KH}$ Murodi Mranggen Demak membutuhkan sentuhan dalam upaya memaksimalkan sampah plastik menjadi suatu barang yang bernilai guna, hal ini dikarenakan sampahsampah plastik di dekat pasar mranggen dan pondok pesantren lebih dari 1 kwintal sehari, sehingga perlu langkah-langkah konkret bagi warga sekitar terutama santri pondok pesantren dalam memaksimlakan sampah-sampah plastik yang ada.

Hasil diskusi pada tahap perancangan menunjukkan bahwa ponpes $\mathrm{KH}$ Murodi sebagai mitra menghendaki bagaimana memproduksi produk dari sampah plastik yang bernilai guna dan mampu diterima produknya dimasyarakat. Berdasarkan hal tersebut maka dirancang pelatihan secara simultan agar benar-benar para santri mampu membuat berbagai 
produk variasi kerajinan sampah plastik secara baik dan layak

Pada tahap proses pembuatan, Tim pengabdian bersama dengan para santri membuat variasi kerajinan sampah plastik. Produk kerajinan yang telah dibuat adalah kerajinan produk sampah plastik dengan Eco-Bricks dibuat menjadi kursi, vas bunga dan mengumpulkan berbagai sampah plastik untuk dibuat tas, dompet, sajadah dan lain-lain.

Keterlibatan anggota santri benarbenar dirasakan karena semangat yang tinggi menjadikan para santri tidak jenuh dalam mengikuti pelatihan dari pagi sampai sore, tim pengabdi melakukan pelatihan bekerjasama dengan berbagai pihak baik dari UPGRIS maupun di luar UPGRIS seperti bank sampah resik becik Semarang yang sudah memproduksi produk sampah plastik secara nasional

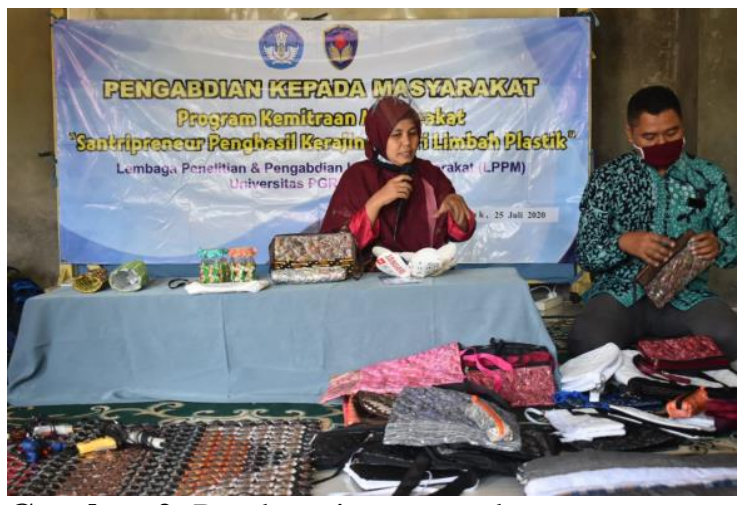

Gambar 2. Pendampingan pembuatan produk kerajinan sampah plastik

Pendampingan pengemasan produk sampah plastik menunjukkan bahwa santri telah mampu mengubah ecobrick hingga menjadi kerajinan bunga. Untuk membuat bunga atau buket bunga dari limbah plastik, caranya sangat mudah. Selain itu bahan-bahan yang digunakan juga mudah didapat yakni limbah plastik, stik bambu serta lem plastic dengan langkah pertama potong plastik kresek memanjang, menjadi tiga bagian. Selanjutnya, tangkupkan lipatan plastik dan digulung pada stik bambu. Agar melekat kuat, plastik tersebut kemudian di lem.

Hal ini sangat mudah dan murah, dalam pembuatannya, yang diperlukan hanya kesabaran serta ketelitian, setelah kelopak bunga sudah jadi, batang bambu kita lilit juga dengan sisa lembaran plastik kresek. Baru kemudian beberapa tangkai bunga yang sudah jadi disatukan, sehingga menjadi buket bunga, dalam hal ini $80 \%$ santri KH Murodi telah mampu mengemas produk seperti sajadah, vas bunga, dompet dan tas secara rapi dan menarik sehingga sangat menarik untuk dipasarkan.

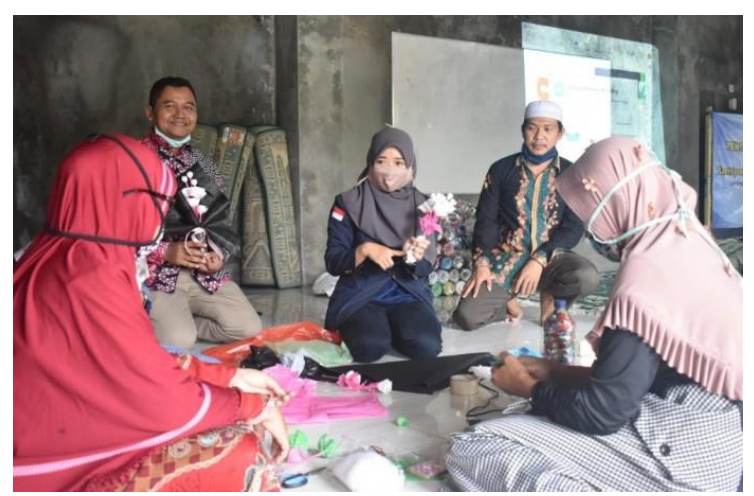

Gambar 3. Pendampingan pengemasan produk kerajinan sampah plastik 
Tim pengabdi juga melakukan pelatihan manajamen pemasaran dan personal finance. Kegiatan melatih manajemen pemasaran maupun finansial agar para santri mampu menghasilkan pasif income tanpa merepotkan orangtua mereka masing-masing.

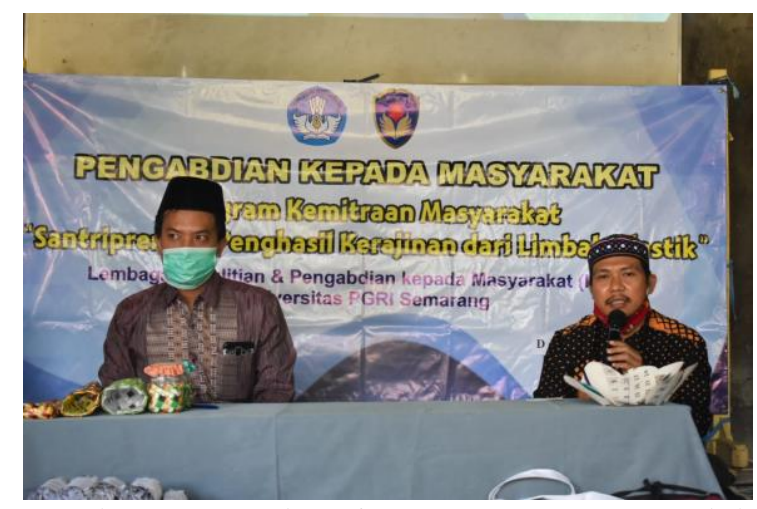

Gambar 4. Pendampingan pemasaran produk kerajinan sampah plastik

Pemasaran produk kerajinan dengan UMKM Resik Becik Semarang dan CV Multi revenue LPPM UPGRIS dalam memasarkan produk hasil kerajinan para santri.

\section{PEMBAHASAN}

Pengabdian kepada masyarakat ini telah melakukan pelatihan pembuatan produk kerajinan dari limbah plastik, kemudian dilatih pengemasan dan pemasaran produk secara simultan sehingga benar-benar dirasakan efeknya bagi para santri KH Murodi Mranggen Demak. Berikut adalah tabel relevansi capaian program pengabdian kepada masyarakat di Pondok Pesantren $\mathrm{KH}$ Murodi Mranggen Demak.

sampah plastik ini telah terjalin kerjasama

Tabel 1. Relevansi kegiatan dengan capaian hasil program PKM Santripreneur

\begin{tabular}{|c|c|c|c|}
\hline No & Permasalahan & Kegiatan & Luaran \\
\hline 1 & $\begin{array}{l}\text { Produktivitas santri pondok } \\
\text { pesantren KH Murodi }\end{array}$ & $\begin{array}{l}\text { Memberikan penyuluhan dan } \\
\text { pendampingan berwirausaha } \\
\text { dibidang variasi kerajinan } \\
\text { sampah plastik }\end{array}$ & $\begin{array}{l}\text { Munculnya semangat } \\
\text { berwirausaha khususnya di } \\
\text { bidang variasi kerajinan } \\
\text { sampah plastik }\end{array}$ \\
\hline 2 & $\begin{array}{l}\text { Kebutuhan santri untuk } \\
\text { peningkatan nilai ekonomi. }\end{array}$ & $\begin{array}{l}\text { Memberikan penyuluhan } \\
\text { tentang ragam produk variasi } \\
\text { kerajinan sampah plastik } \\
\text { Memberikan pelatihan } \\
\text { pembuatan beragam variasi } \\
\text { kerajinan sampah plastik }\end{array}$ & $\begin{array}{l}\text { Tambahan pengetahuan } \\
\text { tentang pembuatan berbagai } \\
\text { jenis variasi kerajinan } \\
\text { sampah plastik } \\
\text { Mampu membuat berbagai } \\
\text { jenis variasi kerajinan } \\
\text { sampah plastik }\end{array}$ \\
\hline 3 & $\begin{array}{l}\text { Pengelolaan pemasaran dan } \\
\text { keuangan dalam wirausaha } \\
\text {. }\end{array}$ & $\begin{array}{l}\text { Memberikan workshop } \\
\text { manajemen pemasaran online } \\
\text { dan pengelolaan keuangan }\end{array}$ & $\begin{array}{l}\text { Pengetahuan dan dorongan } \\
\text { pengelolaan dan pemasaran } \\
\text { produk variasi kerajinan } \\
\text { sampah plastik secara lebiih } \\
\text { luas }\end{array}$ \\
\hline
\end{tabular}

Berdasarkan hasil pengabdian santripreneur, menunjukkan bahwa $80 \%$ santri sangat antusias mengikuti pelatihan variasi kerajinan sampah plastik, hal ini dikarenakan pentingnya life skill bagi para santri dalam mengarungi persaingan 
mencari penghasilan di masyarakat. Hal ini senada dengan hasil yang diperoleh Nasution dalam penelitiannya tentang berbagai cara penanggulangan limbah plastik yang salah satunya dengan variasi kerajinan dari limbah plastik yang memiliki nilai lebih untuk peningkatan ekonomi masyarakat (Nasution, 2015). Studi lain mengenai pemanfaatan sampah plastik menjadi produk dan jasa kreatif menunjukkan adanya bermanfaat bagi kemajuan ekonomi masyarakat (Putra \& Yuriandala, 2010). Selain itu, kegiatan pemberdayaan masyarakat melalui daur ulang sampah plastik pada komunitas Ibu Rumah Tangga Rt. 01/Rw. 12 Desa Limbungan Kecamatan Rumbai Pesisirmayoritas menyatakan 90 persen limbah plastic mampu didaur ulang menjadi produk yang bernilai ekonomis (Hadi dkk., 2017).

Pemberdayaan santri melalui program entrepreneurship dapat meningkatkan kemampuan santri untuk kreatif dan bertahan hidup setelah selesai pendidikan di pondok pesantren (Inayah \& Suprapto, 2017), selain itu dengan memberikan pemahaman yang baik akan pengolahan sampah, santri dapat mewujudkan prinsip kebersihan adalah sebagian dari iman (Kasim dkk., 2018).

\section{SIMPULAN}

Berdasarkan hasil kegiatan PKM Santripreneur, maka dapat disimpulkan sebagai berikut:

1. Santri merasa bersemangat untuk memahami dan melakukan wirausaha/santripreneur sejak dini dan ketrampilan baru dalam menghasilkan pendapatan tambahan;

2. santri memahami pentingnya melakukan pengolahan sampah dan pentingnya memberikan tambahan nilai pada produk berbahan baku sampah plastic;

3. $80 \%$ para santri mampu membuat variasi kerajinan dari sampah plastik dan $20 \%$ lainnya masih perlu pendampingan lebih lanjut,

4. Telah dihasilkan produk kerajinan sampah plastik yang siap dipasarkan

5. pemasaran dilakukan kerjasama dengan UMKM di Semarang dan Demak sehingga dapat menjadikan pasif income bagi para santri.

\section{SARAN}

Meskipun kegiatan berlangsung dengan baik, namun perlu adanya beberapa peningkatan yaitu:

1. Pihak pengasuh pesantren perlu melanggengkan edukasi mengenai santripreneur dan pengolahan sampah; 
2. Perlu dilakukan pendampingan dalam mencari jejaring pemasaran produk dan kualitas produk

\section{UCAPAN TERIMA KASIH}

Ucapan terima kasih kami tujukan pada Kementerian RistekBRIN yang telah memfasilitasi terselenggaranya PKM Santripreneur Terima kasih juga disampaikan kepada LPPM UPGRIS yang telah memberikan dukungan dan penggunaan fasilitas dalam kegiatan pengabdian ini. Serta disampaikan kepada pemerintah Desa Mranggen atas fasilitasi koordinasi dengan para santri selama pelaksanaan kegiatan.

\section{DAFTAR PUSTAKA}

Alrashid, D. A., \& Kahdar, K. (2014).

Eksplorasi Sampah Plastik Menggunakan Metode Fabrikasi untuk Produk Fashion [PhD Thesis]. Bandung Institute of Technology.

Diana, S., Marlina, M., Amalia, Z., \& Amalia, A. (2017). Pemanfaatan sampah plastik menjadi produk kerajinan tangan bernilai ekonomis bagi remaja putus sekolah. Jurnal Vokasi, 1(1), 68-73.

Hadi, M. F., Darwin, R., Widiarsih, D., Hidayat, M., Murialti, N., \& Asnawi, M. (2017). Pemanfaatan
Barang-Barang Bekas Yang

Bernilai Ekonomi Bagi Peningkatan

Produktivitas Jiwa Entrepreneur Ibu Rumah Tangga Rt. 01/Rw. 12 Desa Limbungan Kecamatan Rumbai Pesisir. Jurnal Pengabdian UntukMu NegeRI, 1(2), 42-47. Inayah, N., \& Suprapto, R. (2017). Pendidikan karakter melalui pembentukan bank sampah berbasis pesantren di PP Ibnu Sina Genteng Banyuwangi. PROSIDING, 1(2), 144-156.

Kasim, F., Ridwan, M. K., \& Putra, M. Y. A. (2018). Pengolahan Sampah Plastik Memakai Teknologi Pirolisis Untuk Pembelajaran dan Konservasi Lingkungan di Pondok Pesantren Al-Anwar Sarang Rembang, Jawa Tengah. Jurnal Bakti Saintek: Jurnal Pengabdian Masyarakat Bidang Sains dan Teknologi, 2(2), 57-63.

Muhdi, I., Senowarsito, I., \& Listyaning, S. (2012). Pendidikan Kecakapan Hidup (Life Skills) Melalui Child Friendly Teaching Model (Cftm) Sebagai Dasar Membangun Karakter Siswa. E-Dimas: Jurnal Pengabdian kepada Masyarakat, 3(1), 37-46.

Nasution, R. S. (2015). Berbagai cara penanggulangan limbah plastik. 
Elkawnie: Journal of Islamic

Science and Technology, 1(1), 97-

104.

Putra, H. P., \& Yuriandala, Y. (2010).

Studi pemanfaatan sampah plastik

menjadi produk dan jasa kreatif.

Jurnal Sains \& Teknologi

Lingkungan, 2(1), 21-31.

Widianto, M. W., Budiman, M. A.,

Baedowi, S., Albab, I. U., \&

Kurniawan, A. F. (2017). IbM

SANTRI PONDOK PESANTREN

KH. MURODI MRANGGEN

KABUPATEN DEMAK.

SEMINAR NASIONAL HASIL

PENGABDIAN 2015.

Yunus, M. (2017). Go-Jek Sebagai Simbol

Perubahan Sosial dan Ekonomi di

Kota Tegal. Jurnal Ilmiah

Pendidikan Ekonomi, 2(2), 59-68. 